\title{
Wastewater use in agriculture and potential effects on meso and macrofauna soil
}

\author{
Utilização de efluentes na agricultura e potenciais efeitos na meso e macrofauna do solo
}

\author{
Dinéia Tessaro ${ }^{I}$ Silvio César Sampaio ${ }^{I I}$ Ana Paula Almeida Castaldelli ${ }^{I I I}$
}

\section{ABSTRACT}

The use of wastewater in agriculture has been practiced on an increasing scale over the past decades because of its fertilizing potential and the reduction in demand for surface water and groundwater. However, this practice may bring harm when performed without planning, not respecting the capacity of the soil to recycle organic waste. The most common problems are contamination of surface and groundwater via leaching and runoff, as well as accumulation of nutrients and potentially polluting elements that compromise chemical, physical and biological characteristics of the soil. The biological compartment, represented by the micro, meso and macrofauna, plays an important role in nutrient cycling, decomposition of organic matter, particle movement and transport of materials at different depths, helping to maintain soil physical and chemical characteristics. In this sense, this paper aims to discuss the effect of using different kinds of wastewater in agriculture on soil biology, highlighting strengths and weaknesses, as well as emphasizing the need to conduct investigations that enhance the positive aspects of wastewater use associated with edaphic processes.

Key words: soil biology, edaphic fauna, waste water

\section{RESUMO}

O uso de efluentes na agricultura vem sendo praticado em escala crescente ao longo das últimas décadas em virtude de seu potencial fertilizante e da redução na demanda de águas superficiais e subterrâneas. No entanto, tal prática pode trazer prejuízos quando realizada sem planejamento, não respeitando a capacidade de suporte do solo para a reciclagem de residuos orgânicos. Os problemas mais comuns são a contaminação de águas superficiais e subterrâneas, via lixiviação e escoamento superficial, bem como o acúmulo de nutrientes e elementos potencialmente poluentes que comprometem as características químicas, fisicas e biológicas do solo. O compartimento biológico, representado pela micro, meso e macrofauna, desempenha importante papel na ciclagem de nutrientes, decomposição da matéria orgânica, movimentação das particulas e transporte de materiais em diferentes profundidades, contribuindo para a manutenção das características físicas $e$ químicas do solo. Nesse sentido, o presente trabalho tem por objetivo discutir o efeito do uso de diferentes efluentes na agricultura sobre a biologia do solo, destacando aspectos positivos e negativos, bem como enfatizar a necessidade de conduzir investigações que potencializem os aspectos positivos do uso de efluentes associados aos processos edáficos.

Palavras-chave: biologia de solo, fauna edáfica, águas residuais.

\section{INTRODUCTION}

The soil is the habitat of a number of organisms, such as micro-organisms, and invertebrates with a variety of sizes and metabolisms that play an important role in a number of edaphic processes, which are collectively called soil biota. Estimates for temperate ecosystems indicate that in $1 \mathrm{~m}^{2}$ of soil one may find more than 1 million individuals, among which are observed more than 200 species of arthropods and up to 1000 species of soil fauna organisms in general. Thus, it is believed that the soil-litter system is one of the highest richness and biological diversity reservoirs of the biosphere (COSTA, 2004).

\footnotetext{
'Universidade Tecnológica Federal do Paraná (UTFPR), Campus Dois Vizinhos, Km 04, 85660-000, Dois Vizinhos, PR, Brasil. E-mail: dtessaro@utfpr.edu.br. Corresponding author.

IIDepartamento de Recursos Hídricos e Saneamento Ambiental, Universidade Estadual do Oeste do Paraná (UNIOESTE), Cascavel, PR, Brasil.

IIIPrograma de Pós-graduação em Conservação e Manejo de Recursos Naturais, Universidade Estadual do Oeste do Paraná (UNIOESTE), Cascavel, PR, Brasil. 
While the diversity of groups is extensive and subject to extensive discussion, the bibliographical approach in this research focused on the functions of edaphic fauna, presenting a few concepts and classification definitions of soil organisms, as well as the distribution of the main groups belonging to the meso and macrofauna, focusing on important aspects and relevant results from studies involving such groups and their actions on the environment. However, this is not the main objective of this approach, but the discussion of the effects on soil fauna resulting from the use of organic waste, a still little discussed and studied subject.

\section{DEVELOPMENT}

Use of wastewater in agriculture - benefits and risks Water is a natural resource that is essential for life on the planet, and its potability is being gradually jeopardized by human activities. So, concern over water resources has occupied a prominent place in reuse studies to get answers and alternatives that minimize the negative impacts of modern world on this natural resource.

Water reuse, according BREGA FILHO \& MANCUSO (2003), refers to the use of used water, more often, or in any human activity, to meet the needs of other beneficial uses, including the original and may, direct or indirectly, derive from planned and unplanned actions. Conversely, MIERZWA \& HESPANHOL (2005), highlighted the reuse of water corresponding to the use of effluents, treated or not for beneficial purposes, such as irrigation, industrial use, and non-potable municipal purposes. The term use of wastewater, assumes the use of lower quality water than potable water and therefore constitutes a plausible alternative for less restrictive water demands to be met (WENZEL \& KNUDSEN, 2005).

This theoretical definition, though recent, is already applied in the world for many years, the first accounts arriving from ancient times, as in the case of wastewater irrigation carried out in Athens before Christian Era (PAGANINI, 2003). However, despite this ancient history, ASANO \& LEVINE (1996), point out that reuse gained momentum since 1990 , being implemented in many parts of the world, for different types of use: agricultural, public and industrial, especially in arid and semi-arid regions, where climate imposes serious constraints to agricultural production, almost making local human subsistence unfeasible.

The wastewater in agriculture come from animals breeding such as pig farming, which are rich in nutrients, and used as bio-fertilizers. In addition to being characterized as fertigation, supplying; therefore, water and nutrients to agriculture (CAOVILLA et al., 2010; SAMPAIO et al., 2010) is an important alternative, as it is recognized that agricultural production is the human activity that consumes the most water. In Brazil, about $70 \%$ of the total gathered water is used for agricultural purposes and for irrigation is attributed the highest percentage (HESPANHOL, 2003; MEDEIROS et al., 2005).

The use of these waters; however, should be restricted to treatment, type of cultivation, choice of application methods and control of risks to the environment because, if carried out intensively, it can be harmful to the environment, human health, soil, aquifers and irrigated crops. This potential risk is due to high biochemical and chemical oxygen demand, organic and inorganic pollutants, excess of nutrients, particularly nitrogen and phosphorus, pathogenic micro-organisms and elements that confer salinity to the water and consequently the establishment of salinity frames and sodicity in the soil, affecting its living fraction (MANCUSO \& SANTOS, 2003; TOZE, 2006).

Waste water and waste, most commonly studied in Brazil, are the result of agribusiness activities on a large scale, especially in the production of pigs, cattle, effluents from slaughterhouses, vinasse and those resulting from urban sanitation process, with sewage sludge as an end product. Because of the polluting potential of this waste, studies geared to their reuse in the environment have gained strength and are usually related to physical-chemical soil changes (CAOVILLA et al., 2010; LUCAS et al., 2013; KESSLER et al., 2013), contamination of surface and groundwater (SAMPAIO et al., 2010; SMANHOTTO et al., 2010; MAGGI et al., 2011), and their contributions to crop yields (MENEGHETTI et al., 2008; PELISSARI, 2009).

Also, there is still concern about the wide and indiscriminate use of antimicrobial agents, which found in waste, can lead to genetic resistance in microorganisms and become environmental contaminants (MUNIR et al., 2011; LIU et al., 2013), and only recently increased efforts are being employed in soil biology studies, especially to meso and macrofauna (ALVES et al., 2008; PASQUALIN et al., 2012; TESSARO et al., 2011; TESSARO et al., 2013, CASTALDELLI et al., 2015).

Soil fauna

The term soil fauna refers to the community of organisms living permanently on the ground or which go through one or more 
cycles of their life in it. These organisms are in constant interaction and use the soil as shelter and source of nutrients for their development, so that this occupation ends up influencing directly or indirectly some soil characteristics (ASSAD, 1997). These organisms can be categorized based on a number of morphophysiological attributes; however, due to their body diameter, are classified into microfauna $(<0.2 \mathrm{~mm})$, mesofauna $(0.2$ to $2 \mathrm{~mm}$ ) (KARYANTO et al., 2010) and macrofauna (>2mm) (BIGNEL et al., 2010).

Several authors have highlighted its functions, including nutrient cycling, fragmentation of plant residues, regulating the rate of decomposition of organic matter, improving the physical properties and maintaining of biological balance, composing a sensitive part of the interference in the agricultural environment, due to soil management (ASSAD, 1997; DECAËNS et al., 2003; BARETTA et al., 2003). The changes usually result from soil disturbance, quality of the resulting food of the cultivated plant species, ground cover, application of pesticides and chemical and organic fertilizers and soil and climate conditions such as temperature fluctuations and humidity (HU et al., 1997; ALVES et al., 2008; SANTOS et al., 2008; TESSARO et al., 2011; TESSARO et al., 2013), and such vulnerability to environmental change has led to studies suggesting them as soil quality indicators (BARETTA et al., 2006).

However, this type of investigative approach collides with the complexity of the quantitative and qualitative aspects that involve knowledge of the communities of soil organisms, so that specific groups of organisms are commonly studied associated to certain habitat fractions or groups that perform similar functions in the ecosystem (LAVELLE et al., 1993; GONZÁLEZ et al., 1996).

Effects of the use of waste water on the soil fauna

In view of the foregoing about water demand, high amount of waste generated daily by the various industrial and agro-industrial activities, and the sensitivity of soil organisms, some studies, although still incipient before its functional role, have been conducted to assess their degree of commitment and its potential as a quality indicator of soils subjected to the use of wastewater, which can benefit or not soil organisms, varying according to the amount applied and composition.

In this sense, one of the effluents of more interest about its environmental effects is liquid swine manure. Admittedly, this effluent has a high pollution potential when applied in large doses, not respecting the recyclability and metabolism of a high load of nutrients such as phosphorus and nitrogen, pathogens, heavy metals and antibiotics (MATOS, et al., 2004; LIU et al., 2013), which can change the characteristics of the soil.

Considering this potential, a recent study as the one developed by TESSARO et al. (2013) had as goal evaluate the effect of the application of liquid manure from pigs submitted to biointegrated treatment combined with chemical fertilizer on the density and diversity of the soil's macrofauna in Oxisol cultivated with baby corn. In their evaluations, the authors observed that the different edaphic groups found, presented differentiated responses to the treatments, the most significant being those of Hymenoptera and Collembola groups, which have a bio-indicator potential described by other authors (ALVES et al., 2008; URIBE-HERNÁNDEZ, et al., 2010; BARTZ, et al., 2014; CREPALDI, et al., 2014).

The order Hymenoptera, in the study by TESSARO et al. (2013), represented by the family Formicidae (ants), corresponds to the dominant taxonomic group in most ecosystems, and is present in many different habitats. According to MARINHO et al. (2002), ants are good indicators of areas that have suffered human actions by soil management, industrial pollution as well as successful rehabilitation of degraded areas, thanks to the strong relationship with the vegetation state, soil and decomposition. Some peculiar characteristics of the Formicidae group guarantee this status, such as: high abundance, species richness, ease sampling, separation into morpho-species and specialized taxa able to perceive environmental changes. Among such changes, some authors highlight the family Formicidae as responsive to the amount of organic matter (TESSARO et al., 2013; CREPALDI et al., 2014), the presence of copper (TESSARO, 2013), and lead (BARROS et al., 2010). TESSARO et al. (2013), reported that the ant density increased gradually from the dose of $0 \mathrm{~m}^{3}$ of pig manure to $200 \mathrm{~m}^{3} \mathrm{ha}^{-1}$, followed by a sharp drop in a higher dose, very close to the witness levels.

In a similar study by ALVES et al. (2008), it was reported that the use of pig manure stored in a container for 40 days led to maximum density of the Formicidae group using $50 \mathrm{~m}^{3} \mathrm{~h}^{-1}$. The results of these studies have shown that within certain limits, the use of pig manure with the above characteristics promote improved soil conditions for this group, but becomes a limiting factor at high doses. Still according to the authors, during their study, there was a decrease in the density of these organisms in relation to the initial 
analysis, suggesting that the systematic use of this type of effluent can lead to depletion of the group by the progressive modification of the physicochemical characteristics of the soil.

Soil responses as those described are of paramount importance because the structure of ant communities is essential in the environmental impact study, since they maintain and restore soil quality as well as ac in the redistribution of particles, nutrients and organic matter, improving water infiltration into the soil by increasing the porosity and aeration (LOBRY DE BRUYN, 1999).

Another macrofauana group that has received attention is the order Coleoptera, commonly represented by beetles, which, according to BROWN (1997) is one of the most important soil bioindicators. The order Coleoptera is classified according to ELZINGA (2000) in 160 families, and this large number indicates the evolutionary success of the group. Among the various studies which aimed soil quality by evaluating the group, TESSARO et al. (2013), found reported that the group is responsive when exposed to pig manure and chemical fertilizer simultaneously. Results revealed that the group is positively influenced by the combination of these factors, coinciding with the exposed by ALVES et al. (2008). According to him, the organo-mineral fertilizers favors the occurrence of the group, creating a more conducive environment against the isolated treatments, showing that the combined fertilization generates positive responses. According to THOMANZINI \& THOMANZINI (2002), many of the organisms belonging to this group feed on feces from other organisms so that the use of pig manure may foster a greater abundance of this group compared to treatments without manure. For WARDLE et al. (1995), the Coleoptera group is usually linked to more organic matter in the soil and organic residues on the surface, a more easily condition achieved by combined types of fertilization. Nevertheless, TESSARO et al. (2013) also reported that the group had a certain sensitivity to the application of large volumes of liquid manure even if combined with chemical fertilizer, the amount of organisms being reduced at rates exceeding $100 \mathrm{~m}^{3} \mathrm{ha}^{-1}$, demonstrating the potential of these organisms as bio-indicators under such conditions.

The Oligochaeta order is one of the most important groups in terms of changes in soil structure and high sensitivity to the input of harmful compounds. Their activities lead to the creation of biogenic structures (galleries and coprolites), which modify the physical properties of the soil where they live and the availability of resources for other organisms (JONES et al., 1994). LAVELLE \& SPAIN (2001), point out that the mechanical action on the soil, contribute to the formation of stable aggregates and protect the organic matter from the rapid mineralization, is also a potential source of nutrients available to plants. Considering such importance and scarcity of information available on the effects of organic effluents in the population of soil organisms, CESAR et al. (2008) evaluated in controlled laboratory conditions the toxic potential of sewage sludge in Oxisols and Chernossols on the population of oligochaetes of the Eisenia andrei species. These authors reported that the use of high doses of biosolids led to death or escape of group representatives, demonstrating the high sensitivity and ability to act as indicators of environmental contaminants, especially heavy metals, which are characteristic of the sludge. In a similar study ARTUSO et al. (2010) evaluated the exposure of oligochaets of the species Eisenia fetida to the biosolids in doses equivalent to $0,2,5$, 10 , and $20 \mathrm{t} \mathrm{ha}^{-1}$. As a result, the authors reported that there was a mortality of organisms in doses of 10 and $20 \mathrm{tha}^{-1}$ and reduction in the number of juveniles in doses of 5, 10 and $20 \mathrm{t} \mathrm{ha}^{-1}$.

COULIBALY \& ZORO BI (2010) studied in laboratory conditions the growth and reproduction of oligochaete Eudrilus eugeniae using substrates containing cattle, swine, goats and poultry manure, after 15 days of pre-composting of the material. The results showed no mortality of the adult organisms used in the test, although the production of cocoons was damaged by swine manure, whereas the other residues tested were favorable for the growth and reproduction of the species, indicating its potential to respond actively to different environmental contaminants.

Among the organisms belonging to mesofauna, the Collembola and Acarina groups have received special attention as biological indicators, as they are extremely sensitive individuals, allowing a quick manifestation of environmental changes consequences in their populations (COLEMAN \& HENDRIX, 2000). These edaphic groups can benefit from the addition of organic matter, but they may be affected adversely by the addition of effluents which may contain toxic elements and heavy metals, such as sewage sludge and pig manure (MELO, 2006; BRANDÃO, 2000). In his study using sewage sludge from two treatment plants and at different doses for the corn crop, MELO (2006) reported that there were no significant differences for the Collembola group 
among the tested sludges, or between the control plots, although they presented certain differences in their chemical composition, showing that such a change could not generate considerable effects on the group. However, this should not be a tight consideration because according to the origin of sewage sludge, its characteristics may differ drastically from those described by the author. This condition is reported by PIMENTEL \& WARNEKE (1989), which showed that the liquid sewage sludge use in forest area led to a reduction of soil arthropods in approximately $75 \%$ as compared to the witness, and the populations of mites and springtails were the most affected.

A similar study by BRUCE et al. (1999) showed that sludge contaminated by heavy metals did not affect the total abundance of the Collembola order, but exerted effects on the species, because according to these authors, some species of this group exhibit different behavior relating to a few elements, and some tolerate soils contaminated by heavy metals such as $\mathrm{Zn}, \mathrm{Cu}, \mathrm{Cd}, \mathrm{Ni}, \mathrm{Cr}$ and $\mathrm{Pb}$, while others show no tolerance levels. The lethality of the heavy metals $\mathrm{Cu}$ and $\mathrm{Zn}$, on the Collembola group, was also described by SEGAT (2012), which evaluated the addition of different doses of pig manure stored in a container for 120 days $\left(0,25,50,75\right.$ and $\left.100 \mathrm{~m}^{3}\right)$ to the soil in toxicity testing. ANTONIOLLI et al. (2013) studied the development of the soil springtails with different levels of heavy metals. As a result, the authors found that $\mathrm{Cu}$ and $\mathrm{Zn}$ metals have negative action on the population of springtails, which may be related to the toxic effect that prevents reproduction (SANTORUFO et al., 2012).

According to the results obtained by TESSARO et al. (2011), the Collembola group is able to generate responses to the use of pig manure, with higher density in the dose of $200 \mathrm{~m}^{3} \mathrm{ha}^{-1}$, and in higher doses its overall density is reduced. Similarly ANTONIOLLI et al. (2006), observed that the use of pig manure at a dose of $80 \mathrm{~m}^{3} \mathrm{ha}^{-1}$, favored higher density of these organisms compared to untreated plots. Thus, it seems clear that this type of wastewater has positive effects on the group, ensuring soil conditions that usually do not occur without their addition, on the condition application in which limits are respected. Considering the above, its use could be done moderately, using soil as a filter medium and end of waste disposal, benefiting from the positive aspects resulting from this practice, however, not adversely affecting the order Collembola.

As mentioned, the mites are also potential indicators of soil quality and, together with springtails, correspond to the numerically more representative group, a feature which, associated with its Aptera morphology and sensitivity to changes in physical, chemical and biological soil properties, enables them to be used as indicators of environmental quality (BELLINGER et al., 2014). Given this premise, MELO (2006), reported that the addition of sewage sludge is able to change the density of these organisms according to its chemical composition. According to the author, the Oribatida group, whose individuals act especially in the decomposition of organic matter, was favored by the use of sludge from a station that treats essentially household wastewater if compared to treated plots with sludge resulting from another treatment plant that receives household and industrial sewage whose concentrations of cadmium, copper, lead and chromium are considerably higher.

A similar investigation was carried out by ANTONIOLLI et al. (2006), using pig manure at the rate of $80 \mathrm{~m}^{3} \mathrm{~h}^{-1}$. The authors observed that the coxilha area subjected to treatment showed a lower density of mites compared to the control area. Despite this influence, the study has observed that among the areas evaluated with different types of vegetation, the coxilha area fertilized with swine manure showed high species richness. This result suggested that although some groups, such as dust mites, are more sensitive to this handling, they are less vulnerable to environmental fluctuations. Therefore, there are indications that not all groups have edaphic indicator capability and must be studied carefully, preferably for long periods in view of the range of chemical and physical environmental factors that are part of this dynamic.

Accordingly, CAO et al. (2011) evaluated the changes in the physical and chemical parameters of the soil and the diversity and abundance of the edaphic mites community in treatments with organic fertilizer, chemical and witness, noting that after eleven years of application there was a reduction in the abundance and diversity of mites in treatments with organic and chemical fertilizer. This may be explained by the high amount of phosphorus in the soil of these treatments, which may have been harmful to the fungi in the soil, which are food mycophagous mites.

According to the above, it is evident that many soil organisms are bio-indicators of quality and environmental degradation due to the roles they play in the soil as well as their high degree of sensitivity to environmental changes. Each group of organisms responds differently to disruption, and it is therefore crucial to recognize their interaction with 
environmental changes. However, it is clear that there are still many gaps to be filled regarding the use of meso and macrofauna as an indicator of soil quality, especially in areas subject to application of organic effluents. However, for these gaps to be filled without damage to the living fraction of the soil, studies are needed to assess different environmental conditions and different types of waste.

\section{CONCLUSION}

The soil fauna is affected by the use of different organic wastes, being these changes dependent on the physico-chemical characteristics and amount and frequency of these effluents applications. The changes reported on the various edaphic groups may be positive or negative, depending on the factors described above.

The data presented in the text indicate the bio-indicator potential of the quality of the soil by soil organisms in soils subjected to the use of organic waste, however, there are still many aspects and groups to be studied under different conditions.

\section{ACKNOWLEDGEMENTS}

The authors thank the Conselho Nacional de Desenvolvimento Científico e Tecnológico (CNPq) for doctoral scholarship.

\section{REFERENCES}

ALVES, M.V. et al. Soil macrofauna as influenced by chemical fertilizers and swine manure use in western Santa Catarina state, Brazil. Revista Brasileira de Ciência do Solo, v.32, n.2, p.589598, 2008. Available from: <http://dx.doi.org/10.1590/S010006832008000200014>. Accessed: Apr. 23, 2011. doi: 10.1590/ S0100-06832008000200014.

ANTONIOLLI, Z.I. et al. Alternative method to study soil edaphic fauna. Ciência Florestal, v.16, n.4, p.407-417, 2006. Available from: <http://www.bioline.org.br/pdf?cf06037>. Accessed: Apr. 23, 2011.

ANTONIOLLI, Z.I. et al. Heavy metal, pesticides and fuels: effect in the population of collembola in the soil. Ciência Rural, v.43, n.6, p.992-998, 2013. Available from: <http://www.scielo.br/ scielo.php?script $=$ sci_arttext\&pid $=$ S010384782013000600008\&1 ng=pt\&nrm=iso $>$. Acessed: Nov. 13, 2014. doi: 10.1590/S01038478201300500005 .

ARTUSO, N. et al. Effects of biosolids at varying rates on earthworms (Eisenia fetida) and springtails (Folsomia candida). Applied and Environmental Soil Science, v.2011, p.1-10, 2011. Available from: <http://dx.doi.org/10.1155/2011/519485>. Accessed: Nov. 10, 2014. doi: 10.1155/2011/519485.

ASANO, T.; LEVINE, A.D. Wastewater reclamation, recycling and reuse: past, present and future. Water Science and Technology, v.33, n.10-11, p.1-14, 1996. Available from: <http://dx.doi. org/10.1016/0273-1223(96)00401-5>. Accessed: Apr. 23, 2012. doi: 10.1016/0273-1223(96)00401-5.

ASSAD, M.L.L. Fauna do solo. In: VARGAS, M.A.T.; HUNGRIA, M. Biologia dos solos dos cerrados. Planaltina: EMBRAPACPAC, 1997. p.363-443.

BARETTA, D. et al. Multivariate analysis of soil fauna under different soil tillage and crop management systems. Pesquisa Agropecuária Brasileira, v.4, n.11, p.1675-1679, 2006. Available from: <http:// dx.doi.org/10.1590/S0100-204X2006001100014>. Accessed: Aug. 27, 2015. doi: 10.1590/S0100-204X2006001100014.

BARETTA, D. et al. Soil fauna evaluated by pit fall traps and hand sorting procedures affected by soil management in the western Santa Catarina. Ciências Agroveterinárias, v.2, n.2, p.97-106, 2003.

BARROS, Y.J. et al. Soil quality indicators in lead mining and metalurgy area. II - Mesofauna and plants. Revista Brasileira de Ciência do Solo, v.34, n.4, p.1413-1426, 2010. Available from: <http://dx.doi.org/10.1590/S0100-06832010000400037>. Accessed: Jun. 16, 2014. doi: 10.1590/S0100-06832010000400037.

BARTZ, M.L. et al. The influence of land use systems on soil and surface litter fauna in the western region of Santa Catarina. Revista Ciência Agronômica, v.45, n.5, p.880-887, 2014. Available from: $<$ http://www.ccarevista.ufc.br/seer/index.php/ccarevista/article/ view/3453/1050>. Acessed: Nov. 05, 2014.

BELLINGER, P.F. et al. Checklist of the Collembola of the world. Available from: <http://www.collembola.org $>$. Accessed: Nov. 12, 2014.

BIGNEL, D. et al. Macrofauna. In: MOREIRA, F.S. et al. Manual de biologia dos solos tropicais. Lavras: UFLA, 2010. p.79-129.

BRANDÃO, S.B. et al. Treatment of swine wastewater using organic filters. Revista Brasileira de Engenharia Agrícola e Ambiental, v.4, n.3, p.327-333, 2000. Available from: <http:// dx.doi.org/10.1590/S1415-43662000000300004>. Accessed: Jun. 12, 2012. doi: $10.1590 / \mathrm{S} 1415-43662000000300004$.

BREGA FILHO, D.; MANCUSO, P.C.S. Conceito de reúso de água. In: MANCUSO, P.C.S.; SANTOS, H.F. Reúso de água. Barueri: Manole, 2003. p.21-36.

BROWN, K.S. Insetos como rápidos e sensíveis indicadores de uso sustentável de recursos naturais. In: MARTOS, H.L.; MAIA, N.B. Indicadores ambientais. Sorocaba: PUCC/Shell Brasil, 1997. p.143-151.

BRUCE, L. et al. The effects of sewage sludge on grassland euedaphic and hemiedhafic collembolan populations. Pedobiologia, v.43, p.209-220, 1999.

CAO, Z. et al. Changes in the abundance and structure of a soil mite (Acari) community under long-term organic and chemical fertilizer treatments. Applied Soil Ecology, v.49, p.131-138, 2011. Available from: <http://dx.doi.org/10.1016/j.apsoil.2011.06.003>. Accessed: Jul. 16, 2012. doi: 10.1016/j.apsoil.2011.06.003.

CAOVILLA, F.A. et al. Chemical characteristics of the soil cultivated with soybean and irrigated with swine wastewater. Revista Brasileira de Engenharia Agrícola e Ambiental, v.14, 
n.7, p.692-697, 2010. Available from: <http://dx.doi.org/10.1590/ S1415-43662010000700002>. Accessed: Jul. 25, 2014. doi: 10.1590/S1415-43662010000700002.

CASTALDELLI, A.P.A. et al. Meso e macrofauna do solo cultivado com milho e irrigado com água residuária da suinocultura. Engenharia Agrícola, v.35, n.5, p.905-917, 2015. Available from: <http://dx.doi.org/10.1590/1809-4430-Eng. Agric.v35n5p905-917/2015>. Accessed: Dec. 17, 2015. doi: 10.1590/1809-4430-Eng.Agric.v35n5p905-917/2015.

CESAR, R.G. et al. Toxicity assessment of latosols and chernosols amended with sewage sludge using bioassays with Eisenia andrei earthworms. Anuário do Instituto de Geociências, v.31, n.2, p.33-41, 2008. Available from: <http://www.anuario.igeo.ufrj. br/../2008_2_53_60.pdf $>$. Accessed: Jun. 09, 2012.

COLEMAN, D.C. et al. Invertebrates as webmasters in ecosystems. London, CABI Publishing, 2000. 336p.

COSTA, P. Fauna edáfica e sua atuação em processos do solo. Boa Vista: Embrapa Roraima, 2004. 32p. (Embrapa Roraima. Documentos, 2).

COULIBALY, S.S.; ZORO BI, I.A. Influence of animal wastes on growth and reproduction of the african earthworm species Eudrilus eugeniae (Oligochaeta). European Journal of Soil Biology, v.46, n.2-3, p.225-229, 2010. Available from: $<$ http://www.sciencedirect com/science/article/pii/S116455631000021X\#>. Accessed: Oct. 11, 2014. doi: 10.1016/j.ejsobi.2010.03.004.

CREPALDI, R.A. et al. Ants as bioindicators of soil quality in integrated crop-livestock system. Ciência Rural, v.44, n.5. p.781787, 2014. Available from: <http://dx.doi.org/10.1590/S010384782014000500004>. Accessed: Oct. 14, 2014. doi: 10.1590/ S0103-84782014000500004

DECAËNS, T. et al. Impacto del uso de la tierra en la macrofauna del suelo de los Llanos Orientales de Colômbia. In: JIMÉNEZ, J.J.; THOMAS, R.J. (Ed.). El arado natural: las comunidades de macroinvertebrados del suelo en las savanas neotropicales de Colombia. Cali: Centro Internacional de Agricultura Tropical, 2003. p.21-45. Publicación CIAT, n.336.

ELZINGA, R.J. Fundamentals of entomology. 5.ed. New Jersey: Prentice Hall, 2000. 495p.

GONZÁLEZ, G. et al. Earthworm abundance and species composition in abandoned tropical croplands: comparison of tree plantations and secondary forests. Pedobiologia, v.40, p.385-391, 1996. Available from: <http://www.fs.fed.us/global/iitf/pubs/ jaiitf1996gonzalez001\%20\%20(8).pdf>. Accessed: Oct. 15, 2012.

HESPANHOL, I. Potencial de reúso de água no Brasil agricultura, indústria, município e recarga de aqǘferos. In: MANCUSO, P.C.S.; SANTOS, H.F. Reuso de água. Barueri: Manole, 2003. p.37-96.

HU, F et al. Differentiation of soil fauna populations in conventional tillage and no-tillage red soil ecosystems. Pedosphere, v.7, n.4, p.339-348, 1997. Available from: <http:// file.1w23 .com/6/6c/6cb/6cbd32a4-3fee-4773-a7c5-28ef642cdbe1. pdf $>$. Accessed: Sept. 13, 2012.

JONES, C.G. et al. Organisms as ecosystem engineers. Oikos, v.69, n.3, p.373-386, 1994. Available from: <http://www.jstor.org/ discover $/ 10.2307 / 3545850$ ?uid $=2129 \&$ uid $=2 \&$ uid $=70 \&$ uid $=4 \&$ s $\mathrm{id}=21101648136861>$. Accessed: Sept. 13, 2012.

KARYANTO, A. et al. Collembola, Acari e outros grupos da mesofauna do solo - O método de Berlese. In: MOREIRA, F.S. et al. Manual de biologia dos solos tropicais. Lavras: UFLA, 2010. p.43-76.

KESSLER, N.C.H. et al. Swine wastewater associated with mineral fertilization in black oat (Avena sativa) cultures: 8th production cycle. International Journal of Food, Agriculture and Environment, v.11, n.2, p.1437-1443, 2013. Available from: $<$ http://world-food.net/download/journals/2013-issue2/2013issue2-environment/e120.pdf $>$. Accessed: Nov. 05, 2014.

LAVELLE, P. et al. A hierarchical model for decomposition in terrestrial ecosystem. Application to soils in the humid tropics. Biotropica, v.25, n.2, p.130-150, 1993. Available from: <http:/ www.jstor.org/stable/2389178>. Accessed: Sept. 13, 2012.

LAVELLE, P.; SPAIN, A.V. Soil ecology. Dordrecht: Kluwer Academic, 2001. 654p.

LOBRY DE BRUYN, L.A. Ants as bioindicators of soil functions in rural environments. Agriculture, Ecosystems and Environment, v.74, n.1, p.425-441, 1999. Available from: <http:// dx.doi.org/10.1016/S0167-8809(99)00047-X>. Accessed: Nov. 11, 2012. doi: 10.1016/S0167-8809(99)00047-X.

LIU, L. et al. Elimination of veterinary antibiotics and antibiotic resistance genes from swine wastewater in the vertical flow constructed wetlands. Chemosphere, v.91, p.1088-1093, 2013. Available from: $<$ http://www.sciencedirect.com/science/article/pii/ S0045653513000544>. Accessed: Nov. 04, 2014. doi: 10.1016/j. chemosphere.2013.01.007.

LUCAS, S.D.M. et al. Long-term behavior of $\mathrm{Cu}$ and $\mathrm{Zn}$ in soil and leachate of an intensive no-tillage system under swine wastewater and mineral fertilization. African Journal of Agricultural Research, v.8, p.639-647, 2013. Available from: $<$ http://www.academicjournals.org/article/article1380883460 Lucas\%20et\%20al.pdf $>$. Accessed: Oct. 29, 2014. doi: $10.5897 /$ AJAR12.2063.

MAGGI, C.F. et al. Leaching of nutrients in cultivated soils under application of residual water of pig farming. Revista Brasileira de Engenharia Agrícola e Ambiental, v.15, n. 2, p. 170-177, 2011. Available from: <http://dx.doi.org/10.1590/S1415 43662011000200010>. Accessed: Sept. 08, 2012. doi: 10.1590/ S1415-43662011000200010.

MANCUSO, P.C.S. et al. Reuso de água. São Paulo: Manole, 2003. 576p.

MARINHO, C.G.S. et al. Ant (Hymenoptera: Formicidae) Diversity in Eucalyptus (Myrtaceae) Plantations and Cerrado Litter in Minas Gerais, Brazil. Neotropical Entomology, v.31, n.2, p.187-195, 2002. Available from: <http://dx.doi.org/10.1590/ S1519-18566X2002000200004>. Accessed: Sept. 22, 2012. doi: 10.1590/S1519-18 566X2002000200004.

MATOS, A.T. et al. Nitrate Mobility on Vegetated Soil Ramps for Overland Flow Treatment. Engenharia na Agricultura, v.12, n.1, 57-65, 2004. Available from: <http://www.gpqa.ufv. $\mathrm{br} /$ Publicacoes/escoamento/Mobilidade nitrato solos rampas tratamento.pdf.>. Accessed: Sept. 11, 2012. 
MEDEIROS, S.S. et al. Behavior of the soil chemical attributes in $\mathrm{r} f$ the soil chemical attributes in response to application of wastewater of domestic origin. Revista Brasileira de Engenharia Agrícola e Ambiental, v.9, n.2-3, p.268-273, 2005. Available from: <http:// www.agriambi.com.br/revista/suplemento/index_arquivos/PDF/268. pdf?script $=$ sci pdf $\%$ C09\%03d $=$ S1415-43662005000400004\&lng=e $\mathrm{n} \& n r m=$ iso\&tlng $=\mathrm{pt}>$. Accessed: Sept. 11, 2012.

MELO, L.A.S. Influência de lodos de esgoto nas populações de ácaros e colêmbolos de solo na cultura do milho. In: BETIOL, W.; CAMARGO, O. A. Lodo de esgoto: impactos ambientais na agricultura. Jaguariúna: Embrapa Meio Ambiente, 2006. p.227-234.

MENEGHETTI, A.M. et al. Analysis of growth of minimilho subjected to irrigation depths. Acta Scientarium Agronomy, v.30 n.2, p.211-216, 2008. Available from: <http://periodicos.uem.br/ ojs/index.php/ActaSciAgron/article/view/1730/1018>. Accessed: Sept. 11, 2012. doi: 10.4025/actasciagron.v30i2.1730.

MIERZWA, J.C.; HESPANHOL, I. Água na indústria: uso racional e reuso. São Paulo: Oficina de Textos, 2005. 144p.

MUNIR, M.; XAGORARAKI, I. Levels of antibiotic resistance genes in manure, biosolids, and fertilized soil. Journal of Environment Quality, v.40, p.248-255, 2011. Available from: $<$ https://dl.sciencesocieties.org/publications/jeq/abstracts/40/1/24 8? access $=0 \&$ view $=$ pdf $>$. Accessed: Sept. 12, 2014. doi: 10.2134/ jeq2010.0209.

PAGANINI, W.S. Reuso de água na agricultura. In: MANCUSO, P.C.S.; SANTOS, H.F. Reuso de água. Barueri: Manole, 2003. p.339-402.

PASQUALIN, L.A. et al. Edaphic macrofauna in sugar cane crops and forest in northwestern Paraná - Brazil. Semina: Ciências Agrárias, v.33, n.1, p.7-18, 2012. Available from: <http://www.uel.br/revistas/ uel/index.php/semagrarias/article/viewFile/5210/10128>. Accessed: Jul. 24, 2014. doi: 10.5433/1679-0359.2012v33n1p7.

PELISSARI, R.A.Z. et al. Textile residue and wastewater from swine culture on the Eucalyptus production. Engenharia Agrícola, v.29, n.2, p.288-300, 2009. Available from: <http:// dx.doi.org/10.1590/S0100-69162009000200012>. Accessed: Sept. 13, 2012. doi: 10.1590/S0100-69162009000200012.

PIMENTEL, D. et al. Ecological effects of manure, sewage sludge and other organic wastes on arthropod populations. Agricultural Zoology Rewiews, v.3, p.1-30, 1989.

SAMPAIO, S.S. et al. Ions leaching in deformed and undeformed soil columns. Engenharia Agrícola, v.30, n.1, p.150-159, 2010. Available from: <http://dx.doi.org/10.1590/ S0100-69162010000100016>. Accessed: Oct. 22, 2014. doi: 10.1590/S0100-69162010000100016.

SANTORUFO, L. et al. Soil invertebrates as bioindicators of urban soil quality. Environmental Pollution, v.161, p.57-63, 2012. Available from: $<$ http://www.sciencedirect.com/science/article/pii/ S0269749111005719>. Accessed: Dec. 21, 2012. doi: 10.1016/j. envpol.2011.09.042.
SANTOS, G.G. et al. Soil macrofauna communities and cover crops in a Cerrado Oxisol under no tillage. Pesquisa Agropecuária Brasileira, v.43, n.1, p.115-122, 2008. Available from: <http:// dx.doi.org/10.1590/S0100-204X2008000100015>. Accessed: Oct. 09, 2012. doi: 10.1590/S0100-204X2008000100015.

SEGAT, J.C. Avaliação ecotoxicológica do uso de dejetos suínos em solos de Santa Catarina. 2012. 130f. Dissertação (Mestrado em Solos e Nutrição de Plantas) - Curso de Pós-graduação em Solos e Nutrição de Plantas, Escola Superior de Agricultura "Luiz de Queiroz", Piracicaba, SP.

SMANHOTTO, A. et al. Copper and zinc in the lixiviated material and in the soil application of swine wastewater on soil cultivated with soybean. Engenharia Agrícola, v.30, n.2, p.347357, 2010. Available from: <http://dx.doi.org/10.1590/S010069162010000200017>. Accessed: Jan. 03, 2012. doi: 10.1590/ S0100-69162010000200017.

TESSARO, D. et al. Edaphic mesofauna (springtails and mites) in soil cultivates with baby corn and treates with swine wastewater combined with chemical fertilization. Journal of Food, Agriculture and Environment, v.9, n.3-4, p.983-987, 2011. Available from: $<\mathrm{http}: / / \mathrm{www}$.isfae.org/scientficjournal/2011/ issue3/pdf/Environment/067.pdf>. Accessed: Nov. 02, 2012.

TESSARO, D. et al. Macrofauna of soil treated with swine wastewater combined with chemical fertilization. African Journal of Agricultural Research, v.8, n.1, p.86-92, 2013. Available from: <http://www.academicjournals.org/ajar/PDF/pdf2013/8Jan/ Tessaro\%20et\%20al.pdf $>$. Accessed: Feb. 02, 2013. doi: 10.5897/ AJAR12.1829.

THOMANZINI, M.J.; THOMANZINI, A.P.B.W. Levantamento de insetos e análise entomofaunística em floresta, capoeira e pastagem no Sudeste Acreano. Rio Branco: Embrapa Acre, 2002. 41p. (Circular Técnica, 35).

TOZE, S. Reuse of effluent water-benefits and risks. Agricultural Water Management, v.80, p.147-159, 2006. Available from: $<$ http://dx.doi.org/10.1016/j.agwat.2005.07.010>. Accessed: Sept. 13, 2012. doi: 10.1016/j.agwat.2005.07.010.

URIBE-HERNÁNDEZ, R. et al. Collembola (Hexapoda) as quality bioindicators of the hydrocarburans polluted soils in Southestern Mexico. Revista Mexicana de Biodiversidad, v.81, n.1, p.153-162, 2010. Available from: <http://www.scielo.org.mx/ scielo.php?pid $=$ S1870-34532010000100020\&script $=$ sci arttext $>$. Accessed: Nov. 12, 2014.

WARDLE, D.A. et al. The detritus foo-web and the diversity of soil fauna as indicators of disturbance regimes in agro-ecosystems. Plant and Soil, v.170. n.1, p.35-43, 1995. Available from: <http:// link.springer.com/article/10.1007\%2FBF02183053?LI=true $>$. Accessed: Sept. 11, 2012. doi: 10.1007/BF02183053.

WENZEL, H.; KNUDSEN, H.H. Water savings and reuse in the textile industry. In: OMELCHENKO, A. et al. Modern tools and methods of water treatment for improving living standards. Amsterdam: Springer Netherlands, 2005. p.169-189. 